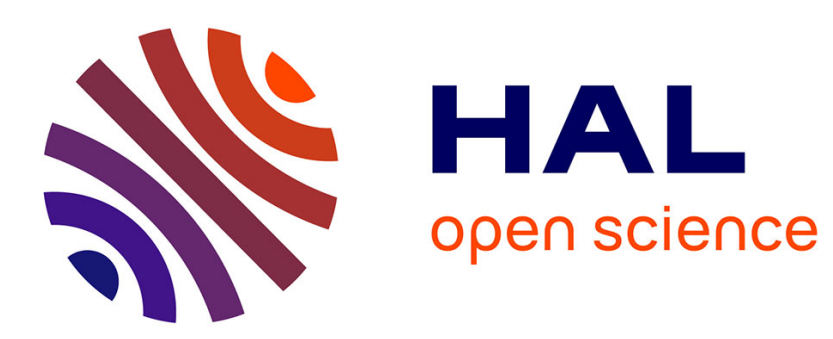

\title{
Small-cell comb does not control Varroa mites in colonies of honeybees of European origin \\ Thomas Seeley, Sean Griffin
}

\section{To cite this version:}

Thomas Seeley, Sean Griffin. Small-cell comb does not control Varroa mites in colonies of honeybees of European origin. Apidologie, 2011, 42 (4), pp.526-532. 10.1007/s13592-011-0054-4 . hal-01003589

\section{HAL Id: hal-01003589 \\ https://hal.science/hal-01003589}

Submitted on 1 Jan 2011

HAL is a multi-disciplinary open access archive for the deposit and dissemination of scientific research documents, whether they are published or not. The documents may come from teaching and research institutions in France or abroad, or from public or private research centers.
L'archive ouverte pluridisciplinaire HAL, est destinée au dépôt et à la diffusion de documents scientifiques de niveau recherche, publiés ou non, émanant des établissements d'enseignement et de recherche français ou étrangers, des laboratoires publics ou privés. 


\title{
Small-cell comb does not control Varroa mites in colonies of honeybees of European origin
}

\author{
Thomas D. Seeley, Sean R. Griffin \\ Department of Neurobiology and Behavior, Cornell University, Ithaca, NY 14853, USA \\ Received 9 July 2010 - Revised 26 September 2010 - Accepted 4 October 2010
}

\begin{abstract}
We tested the idea that Varroa destructor can be controlled in colonies of the European subspecies of Apis mellifera by providing them with combs built of small cells, in which immature mites might have difficulty developing for lack of space. We established seven pairs of equal-size colonies that started out equally infested with mites. In each pair, one hive contained only standard-cell $(5.4 \mathrm{~mm}) \mathrm{comb}$, and the other contained only small-cell $(4.8 \mathrm{~mm})$ comb. We measured the colonies' mite loads at monthly intervals across a summer. No differences arose between the two treatment groups in their mean mite loads (mites per 100 worker bees or mite drop per $48 \mathrm{~h}$ ). We suggest that providing small-cell combs did not inhibit mite reproduction because the fill factor (thorax width/cell width) was only slightly higher in the small cells than in the standard cells (79\% and $73 \%$, respectively).
\end{abstract}

Apis mellifera / Varroa destructor / small cell / mite control / cell size

\section{INTRODUCTION}

The mite Varroa destructor is a new parasite of European honeybees living in North America, having been introduced to these bees only in the mid-1980s (Wenner and Bushing 1996; Sanford 2001). This mite and its associated viruses are a major cause of colony mortality worldwide. As a rule, if a colony of European honeybees does not receive mite control treatments, the mite population will grow from just a few mites to several thousand mites in 3 to 4 years, ultimately killing the colony (Ritter 1988; Korpela et al. 1992; Wenner and Thorp 2002). One possible nonchemical method of mite control that has been much discussed and debated (e.g., Erickson et al. 1990; Johnsen 2005) is to reduce worker cell width from the current size of 5.2-5.5 to $4.9 \mathrm{~mm}$. It has been suggested (e.g., Medina and Martin

Corresponding author: T.D. Seeley, tds5@cornell.edu

Manuscript editor: Marla Spivak
1999) that smaller cells may cause higher mortality of immature mites, because the mites develop directly beside immature bees in cells (Donzé and Guerin 1997) so a smaller space between the developing bee and the cell wall might hamper the movements of the immature mites, reducing their ability to feed and thereby raising their mortality.

One study that has provided support for the concept of small-cell combs for Varroa mite control was conducted in South Africa with African honeybees (Martin and Kryger 2002). Colonies were established in which larger bees (Apis mellifera capensis, similar in size to European bees) and smaller bees (A. m. scutellata, smaller than European bees) were reared together in small-cell $(4.6 \mathrm{~mm})$ combs, and it was found that both mother mite mortality and male offspring mite mortality were higher in the cells with larger bees. The authors report that mother mites and male protonymphs appeared to get trapped in the upper part of the cells that contained the larger bees, thereby preventing the 
mites from reaching the feeding site on the abdomen of the developing bee pupa. This is, however, a special case in which some of the largest worker bees found in A. mellifera were reared in some of the smallest cells produced by A. mellifera, and it may be that the elevated mite mortality that was observed requires such extreme conditions.

A second relevant study is that of McMullan and Brown (2006). Working with A. m. mellifera in Ireland, they gave colonies small-cell $(5.04 \mathrm{~mm})$ combs and standard-cell $(5.48 \mathrm{~mm})$ combs and found that the worker bees reared in the small-cell combs were less than $1 \%$ smaller (in head width and thorax width) than those reared in the standard-cell combs, even though the small cells were $8 \%$ less wide than the standard cells. Evidently, when bees are reared in small cells, the reduction in bee size is not proportional to the reduction in cell size, so the cell "fill factor" (thorax width/cell width, expressed as a percentage) is higher and there is less room for the mites. McMullan and Brown (2006), for example, found that the fill factor was $73 \%$ in colonies with standard-cell combs but $79 \%$ in ones with small-cell combs.

Three recent studies conducted either in the southeastern USA (Ellis et al. 2009; Berry et al. 2010) or in Ireland (Coffey et al. 2010) have directly tested the idea that giving combs of small cells to colonies of European honeybees will reduce their susceptibility to Varroa. All three studies found no evidence that providing colonies with small-cell combs rather than standard-cell combs impedes reproduction by Varroa. A fourth recent study on this subject, conducted in New Zealand (Taylor et al. 2008) also found no effect of cell size on mite infestation, but this fourth study was confounded by difficulty in getting the bees to build combs consisting entirely of small cells, resulting in small differences in cell size between the two treatment groups. In the present study, we extended this work by conducting a test in the northeastern USA in which we established pairs of colonies, with each pair consisting of one colony living in a hive containing standard-cell combs and one colony living in a hive contain- ing small-cell combs. To be certain that the small-cell combs in our study consisted entirely of small cells, we used small-cell combs built of plastic. The two colonies in each pair were started as artificial swarms made from the same source colony and with closely matched mite loads. We then measured the mite loads of the bees in the paired colonies at monthly intervals across a summer to see if the colonies living in hives equipped with small-cell combs showed signs of reduced reproduction by the mites.

\section{MATERIALS AND METHODS}

The study was conducted over the summer of 2009 in Ithaca, NY, USA. On June 2, we prepared 14 $1.0-\mathrm{kg}$ (=approximately 7,700 bees) packages of honeybees, 2 from each of 7 strong colonies that had scored highly in a Varroa mite drop test conducted 6 weeks earlier, on April, 18-20; 77, 26, $34,66,53,55$, and 37 mites per colony collected on a sticky board in $48 \mathrm{~h}$. We did not treat the seven source colonies for mites before we shook the bees from them for our packages, so we could be confident that the bees in our packages were well infested with mites. We could also be confident that both packages in a pair had similar numbers of mites (this was also checked, as described below) because the bees in each pair of packages came from the same source colony. Each package was given a new Minnesota Hygienic queen (Olivarez Honey Bees, Inc., Chico, CA, USA).

Immediately after making the packages, we began feeding them with a $50 / 50(v / v)$ sucrose solution brushed onto the wire screen of one side of each package cage. We continued this feeding for the next 3 days, June 3-5. On the evening of June 5, we installed each package in a single-story deep Langstroth hive containing ten frames of comb. One package in each pair was installed in a hive containing frames of standard-cell comb built of beeswax, and the other package in each pair was installed in a hive containing frames of small-cell comb built of plastic (Honey Super Cell, Westmorland, CA,USA). (Note: We used plastic combs to be certain that the colonies that received the small-cell treatment had only small cells in their combs. We 
failed in two attempts in 2007 and 2008 to get our bees to build beeswax combs consisting entirely of small cells by giving them frames containing smallcell foundation (4.9 mm, Dadant and Sons, Hamilton, IL, USA).) There were no drone cells in any of the frames of comb used in this study. We measured the mean width of the cells in each hive by measuring the width of ten cells in a straight line (inclusive of wall widths) in the center of one side of each frame of comb. For the seven hives with standard-cell combs, the mean cell widths were $5.38,5.40,5.40,5.36$, $5.39,5.38$, and $5.38 \mathrm{~mm}$, hence $5.38 \mathrm{~mm}$ on average. For the seven hives with small-cell combs, the mean cell widths were all the same: $4.82 \mathrm{~mm}$. Thus, there was a mean reduction in cell width in the small-cell combs of $0.56 \mathrm{~mm}$, or $10.4 \%(0.56 / 5.38=0.104)$.

Both groups of hives (those with standard-cell combs or small-cell combs) were located at the Liddell Field Station, but were arranged in separate apiaries spaced $120 \mathrm{~m}$ apart. Within each apiary, adjacent hives were spaced $5 \mathrm{~m}$ apart. We put all the colonies in the same general area to minimize location effects on any differences we might find between the two group, but in different apiaries to minimize transmission of Varroa mites between the two groups. We managed the colonies for honey production, giving each one a second deep hive body containing frames of standard-cell or small-cell combs in early July to prevent swarming and to provide more space for brood rearing and honey storage.

Once a month - from mid-June to mid-Octoberwe took measurements of three variables: (1) the strength of each colony, (2) the infestation level of Varroa mites in each colony, and (3) the size of the workers in each colony. To measure colony strength, we counted the number of frames of adult bees and brood in each colony, doing so by visually examining each side of each comb and estimating what fraction $(1 / 4,2 / 4,3 / 4$, or $4 / 4)$ was covered with adult bees and what fraction was filled with brood. To measure the level of the Varroa mite infestation, we used two methods. First, 2-6 days before we opened the hives for the detailed visual inspections, we installed in each hive a sticky board (Dadant and Sons, Hamilton, IL, USA) for $48 \mathrm{~h}$ to get a 48 -h mite drop count. Second, when we opened the hives to inspect the combs of each colony, we collected from the brood region of each colony's nest a sample of $250 \mathrm{~mL}$ of bees (approximately 300 bees) and used the powdered sugar method to determine the number of mites on these bees. (The bees and mites from each colony were returned to it after we made our measurement.) To measure the size of the workers in each colony, each time we made a visual inspection of a colony, we collected from its brood nest region a sample of ten worker bees and measured each bee's head width $( \pm 0.02 \mathrm{~mm}$ ) using a dissecting scope equipped with an ocular micrometer. In the summer of 2010, we measured the thorax widths of bees collected from the five surviving colonies with standard-cell combs and from two new colonies with small-cell combs. All the original colonies with small-cell combs died over the winter of 2009-2010, so we set up two colonies on small-cell combs in spring 2010, to get bees reared in small-cell combs for thorax width measurements.

When we took our monthly measurements of the colonies, we cut out any drone comb that the colonies had built, usually along the bottoms of the frames. At most, this involved removing 25 drone cells per colony per inspection; none of the drone comb contained drone brood. In this way, we prevented drone rearing in our colonies and this meant that all the mite reproduction in our study colonies occurred in cells of worker brood. This ensured that our measurements of the number of Varroa mites in our colonies would reflect a difference, if any, in mite reproduction between hives equipped with just standard-size worker cells and just small-size worker cells.

All descriptive statistics are reported as the mean \pm SE. To test for differences between the means of variables measured in both the standard-cell and the small-cell colonies, we used paired comparisons $t$ tests (Sokal and Rohlf 1981) to take advantage of the initial pairing of the study colonies.

\section{RESULTS}

\subsection{The two treatment groups started with matching distributions of mites per colony}

To see if the two treatment groups started out well matched in terms of numbers of mites per colony, we checked whether the initial counts of 
mites per 100 adult bees were similar for the two colonies produced from each of the seven source colonies. Figure 1 shows that there were differences in mean mite load among the seven pairs of colonies, but that the two colonies in each pair were closely matched in their mite loads (correlation coefficient $=0.88$, paired comparisons $t$ test, $t_{6}=1.24, P>0.25$ ). It is clear, therefore, that the two treatment groups started out with virtually identical distributions of mites per colony.

\subsection{The two treatment groups ended the summer with similar mite infestations}

Table I summarizes our findings regarding the mite loads in the colonies of the two treatment groups, measured in terms of mites per 100 adult bees. It shows that for both treatment groups, the mite loads started at a relatively high level in June, then dropped to lower levels in July and August, and eventually

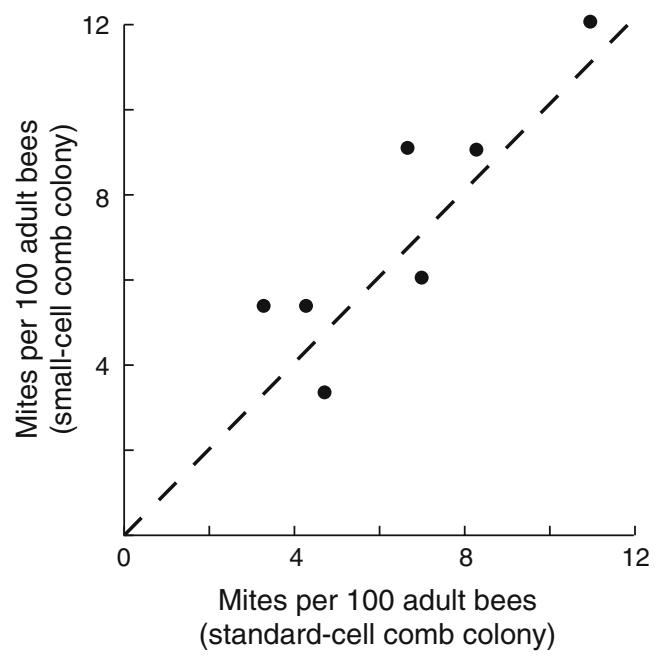

Figure 1. Correlation plot that shows how the two colonies in each pair of colonies used in the study started out with similar loads of Varroa mites. The two colonies in each pair were established using $1.0 \mathrm{~kg}$ of bees taken from the same mite-infested source colony. In each pair, one colony was given standard-cell combs and the other was given smallcell combs. increased in September and October. At no point did we detect a difference in number of mites per 100 adult bees between the colonies living on standard-cell combs and those living on small-cell combs.

Table II summarizes our findings regarding the mite loads in the colonies of the two treatment groups, measured in terms of mites caught on sticky boards over a 48 -h period (="mite drop count"). It shows that for both treatment groups, the mean mite drop count rose gradually over the summer and that the mean mite drop count never differed significantly between the two groups. The mean mite drop counts were slightly lower (though not significantly so) for the small-cell colonies in July, August, September, and October, but we suspect that this trend was a result of the small-cell colonies being smaller than the standard-cell colonies. The colonies in the hives with the plastic, small-cell combs grew noticeably less rapidly than those in the hives with the beeswax, standard-cell combs. For example, by the middle of August, the mean numbers of frames of adult bees and frames of brood in the small-cell colonies were only $4.2 \pm 0.7$ and $3.0 \pm$ 0.4 , whereas in the standard-cell colonies they were $7.7 \pm 0.8$ and $5.5 \pm 0.5$.

To compensate for the difference in mean colony size between the treatment groups, we divided each colony's mite drop count by the number of frames of adult bees. This yielded a value of mites/sticky board/48 h/frame of bees. The results are summarized in Table II. We see

Table I. Comparisons of the number of mites per 100 adult bees between colonies living on standard-cell combs vs. small-cell combs.

\begin{tabular}{cccc}
\hline \multirow{2}{*}{ Date } & \multicolumn{2}{c}{ Mites per 100 adult bees } & \multirow{2}{*}{$P$ value } \\
\cline { 2 - 3 } & Standard-cell & Small-cell & \\
\hline June 16 & $6.48 \pm 1.00$ & $7.14 \pm 1.12$ & $>0.50$ \\
July 16 & $2.33 \pm 0.58$ & $3.33 \pm 0.79$ & $>0.25$ \\
Aug 12 & $1.81 \pm 0.62$ & $3.00 \pm 1.11$ & $>0.50$ \\
Sept 19 & $4.71 \pm 1.42$ & $6.62 \pm 0.84$ & $>0.15$ \\
Oct 17 & $6.45 \pm 0.83$ & $8.43 \pm 1.00$ & $>0.20$ \\
\hline
\end{tabular}


that this correction for colony size differences between the two treatment groups eliminates the suggestion of fewer mites in the small-cell colonies. Indeed, there is evidence that by the end of the summer, in September and October, the number of mites per adult bee was becoming higher in the small-cell colonies than in the standard-cell colonies.

Table III summarizes our findings regarding worker bee head width across the summer for bees in the standard-cell and the small-cell colonies. We see that there was a slight (approximately $0.08 \mathrm{~mm}$, or $2.1 \%$ ), but significant $(P<0.01)$, reduction in head width in the small-cell colonies, but that there was no change in head width in the standard-cell colonies. Table III also shows our findings regarding worker bee thorax width for bees in the two types of colony. We see that there was a slight (approximately $0.14 \mathrm{~mm}$ or $3.5 \%$ ), but significant $(P<0.01)$, difference in thorax width between the two types of colonies.

\section{DISCUSSION}

Despite our hope that equipping colonies of European honeybees with small-cell combs would protect them from Varroa by inhibiting the mite's reproduction, we found no evidence of this in our study. We used manufactured plastic combs for our small-cell treatment, and we removed from all our hives any drone comb that the bees built, so there can be no doubt that the colonies in our small-cell treatment group had only small cells (mean width $4.82 \mathrm{~mm}$ ) in their combs and that the colonies in our standard-cell treatment group had only standard cells (mean width $5.38 \mathrm{~mm}$ ) in their combs. Despite this unambiguous difference in cell size between our two treatment groups, we found no difference in number of mites per 100 worker bees or in mite drop count between the two treatment groups. If it were the case that Varroa reproduction on European honeybees is impeded when these mites parasitize bees living on small-cell combs, then over the summer, we should have seen a decline in the mite levels in the small-cell colonies relative to the mite levels in the standard-cell colonies. But we saw no sign of such a decline. On the contrary, we found that the mean mite counts started out the same for the two groups of colonies and remained indistinguishable over the next 4 months. We conclude that the small-cell treatment did not hamper the growth of the populations of Varroa mites in our study colonies in the northeastern USA (NY state), a conclusion that echoes those of two analogous studies conducted in the southeastern USA (Florida and Georgia) (Ellis et al. 2009; Berry et al. 2010) and one study conducted in Ireland that examined mite reproduction in small-cell $(4.91 \mathrm{~mm})$ and standard-cell $(5.38 \mathrm{~mm})$ combs (Coffey et al. 2010).

Likewise, our findings regarding the effect of reducing cell size on bee size are consistent with what McMullan and Brown (2006) have reported. When they gave colonies either small-cell $(5.04 \mathrm{~mm})$ combs or standard-cell $(5.48 \mathrm{~mm})$ combs, they found that the bees

Table II. Comparisons of the counts of mites caught on a sticky board over $48 \mathrm{~h}$ between colonies living on standard-cell combs vs. small-cell combs.

\begin{tabular}{|c|c|c|c|c|c|c|}
\hline \multirow[t]{2}{*}{ Date } & \multicolumn{2}{|c|}{ Mites/sticky board/48 h } & \multirow[t]{2}{*}{$P$ value } & \multicolumn{2}{|c|}{ Mites/sticky board/48 h/frame of bees } & \multirow[t]{2}{*}{$P$ value } \\
\hline & Standard-cell & Small-cell & & Standard-cell & Small-cell & \\
\hline June 10 & $11.2 \pm 3.5$ & $13.4 \pm 3.2$ & $>0.50$ & $5.12 \pm 1.80$ & $4.65 \pm 1.27$ & $>0.50$ \\
\hline July 13 & $21.9 \pm 8.7$ & $15.9 \pm 3.8$ & $>0.50$ & $7.33 \pm 3.12$ & $6.19 \pm 1.49$ & $>0.60$ \\
\hline Aug 10 & $27.1 \pm 5.7$ & $23.4 \pm 2.9$ & $>0.40$ & $3.61 \pm 0.62$ & $4.04 \pm 1.09$ & $>0.60$ \\
\hline Sept 17 & $46.1 \pm 10.6$ & $39.0 \pm 12.4$ & $>0.40$ & $4.13 \pm 0.44$ & $7.50 \pm 2.39$ & $>0.50$ \\
\hline Oct 16 & $55.6 \pm 10.1$ & $52.1 \pm 11.4$ & $>0.40$ & $5.24 \pm 0.69$ & $10.65 \pm 2.51$ & $>0.15$ \\
\hline
\end{tabular}


Table III. Comparisons of the head widths and thorax widths of worker bees between colonies living on standard-cell combs vs. small-cell combs.

\begin{tabular}{lclc}
\hline \multicolumn{1}{c}{ Date } & Standard-cell & Small-cell & $P$ value \\
\hline Head width (mm) & & & \\
16 June 2009 & $3.80 \pm 0.02$ & $3.78 \pm 0.01$ & $>0.50$ \\
16 July 2009 & $3.76 \pm 0.01$ & $3.71 \pm 0.01$ & $<0.01$ \\
12 Aug 2009 & $3.76 \pm 0.01$ & $3.70 \pm 0.02$ & $<0.01$ \\
19 Sept 2009 & $3.78 \pm 0.01$ & $3.70 \pm 0.02$ & $<0.01$ \\
17 Oct 2009 & $3.78 \pm 0.01$ & $3.70 \pm 0.01$ & $<0.01$ \\
Thorax width (mm) & & & $<0.01$ \\
7 Sept 2010 & $3.95 \pm 0.03$ & $3.81 \pm 0.03$ & \\
\hline
\end{tabular}

reared in small-cell combs were only about $1 \%$ smaller (in head width and thorax width) than those reared in standard-cell combs, even though the small cells were $8 \%$ less wide than the standard cells. Similarly, we found that bees reared in our small-cell combs $(4.82 \mathrm{~mm})$ were only $2.1 \%$ smaller in head width and $3.5 \%$ smaller in thorax width than those reared in our standard-cell combs, even though our small cells were $10.4 \%$ less wide than our standard cells. It seems clear now that when bees are reared in small cells, the reduction in bee size is not proportional to the reduction in cell size.

The concept of small-cell combs as a nonchemical means of Varroa mite control seemed to be supported by the finding reported by Martin and Kryger (2002) that when relatively large worker bees (A. m. capensis) and relatively small worker bees (A. m. scutellata) were reared together in the small-cell $(4.6 \mathrm{~mm})$ combs of $A$. $m$. scutellata, many fewer fertilized females mites were produced in cells containing the larger bees. They also reported that the low reproductive success of mites in cells with the larger bees was due to high levels of mother mite and male protonymph mite mortality. Martin and Kryger (2002) surmised that the reason for the higher mite mortality in cells with larger bees was a lack of space for the mites to move around inside the cells holding the big bees. This may have occurred in the situation studied by Martin and Kryger (2002), because their investigation involved some of the largest workers of $A$. mellifera (those of A. m. capensis) being reared in some of the smallest cells of $A$. mellifera (those of A. m. scutellata, approximately $4.6 \mathrm{~mm}$ wide).

It now seems highly doubtful, however, that when workers of the European races of $A$. mellifera are reared in small cells $(4.8 \mathrm{~mm}$, this study; or $4.9 \mathrm{~mm}$, Ellis et al. 2009, Berry et al. 2010, Coffey et al. 2010), the fill factor is high enough to inhibit mite reproduction and so achieve mite control. We measured the fill factor (the ratio of thorax width to cell width, expressed as a percentage) for both the standard-cell combs and the small-cell combs in our study. The bees reared in our standardcell combs had a mean thorax width of $3.95 \mathrm{~mm}$ and, thus, a fill factor of $3.95 / 5.38=73 \%$, whereas the bees reared in our small-cell combs had a mean thorax width of $3.81 \mathrm{~mm}$ and, thus, a fill factor of $3.81 / 4.82=79 \%$. These values of fill factor are identical to those reported by McMullan and Brown (2006) for A. m. mellifera in Ireland reared on standard-cell $(5.48 \mathrm{~mm})$ and small-cell $(5.04 \mathrm{~mm})$ combs: $73 \%$ and $79 \%$. Because the fill factors were rather low for both groups of bees, and only slightly higher for the bees living on small-cell combs, it is perhaps not surprising that we found no evidence in support of the notion that small-cell combs hinder the reproduction of mites on European honeybees.

\section{ACKNOWLEDGMENTS}

This research was supported by the US Department of Agriculture (Hatch grant NYC-191522). We thank 
Professor Nicholas Calderone and two reviewers for providing helpful comments on the manuscript.

La diminution de la taille des cellules des rayons ne réduit pas l'infestation par Varroa destructor dans les colonies d'abeilles d'origine européenne.

Apis mellifera / Varroa destructor / taille de la cellule / lutte anti-acarien / cellule réduite

\section{Waben mit kleinen Zellen sind nicht geeignet um den Varroabefall in Völkern der europäischen Honigbienen zu kontrollieren.}

\section{Apis mellifera / Varroa destructor / kleine Zellen / Milbenkontrolle / Zellgröße}

\section{REFERENCES}

Berry, J.A., Owens, W.B., Delaplane, K.S. (2010) Smallcell comb foundation does not impede Varroa mite population growth in honey bee colonies. Apidologie 41, 40-44

Coffey, M.F., Breen, J., Brown, M.J.F., McMullan, J.B. (2010) Brood-cell size has no influence on the population dynamics of Varroa destructor mites in the native western honey bee, Apis mellifera mellifera. Apidologie 41, 522-530

Donzé, G., Guerin, P.M. (1997) Time-activity budgets and space structuring by the different life stages of Varroa jacobsoni in capped brood of the honey bee Apis mellifera. J. Insect Behav. 10, 371-393

Ellis, A.M., Hayes, G.W., Ellis, J.D. (2009) The efficacy of small cell foundation as a Varroa mite (Varroa destructor) control. Exp. Appl. Acarol. 47, 311-316

Erickson, E.H., Lusby, D.A., Hoffman, G.D., Lusby, E. W. (1990) On the size of cells: speculations on foundation as a colony management tool, Glean. Bee Culture 118(98-101), 173-174

Johnsen, H.-O. (2005) Commercial beekeeping in Norway. Bee Culture 133, 37-40

Korpela, S., Aarhus, A., Fries, I., Hansen, H. (1992) Varroa jacobsoni Oud. in cold climates: population growth, winter mortality and influence on survival of honey bee colonies. J. Apic. Res. 31, 157-164

Martin, S.J., Kryger, P. (2002) Reproduction of Varroa destructor in South African honey bees: does cell space influence Varroa male survivorship? Apidologie 33, 51-61

McMullan, J.B., Brown, M.J.F. (2006) The influence of small-cell brood combs on the morphometry of honeybees (Apis mellifera). Apidologie 37, 665-672

Medina, L.M., Martin, S.J. (1999) A comparative study of Varroa jacobsoni reproduction in worker cells of honey bees (Apis mellifera) in England and Africanized bees in Yucatan, Mexico. Exp. Appl. Acarol. 23, 659-667

Ritter, W. (1988) Varroa jacobsoni in Europe, the tropics and subtropics. In: Needham, G.R., Page, R.E., Delfinado-Baker, M., Bowman, C.E. (eds.) Africanized honey bees and bee mites, Ellis Horwood, Chichester pp. 349-359.

Sanford, M.T. (2001) Introduction, spread, and economic impact of Varroa mites in North America. In: Webster, T.C., Delaplane, K.S. (eds.) Mites of the honey bee, Dadant and Sons, Hamilton, Illinois pp. 149-162.

Sokal, R.R., Rohlf, F. J. (1981) Biometry. Freeman, NY

Taylor, M.A., Goodwin, R.M., McBrydie, H.M., Cox, H. M. (2008) The effect of honeybee worker brood cell size on Varroa destructor infestation and reproduction. J. Apic. Res. 47, 239-242

Wenner, A.M., Bushing, W.W. (1996) Varroa mite spread in the United States. Bee Culture 124, 342-343

Wenner, A.M., Thorp, A.M. (2002) Collapse and resurgence of feral colonies after Varroa arrival. In: Erickson, E.H., Page, R.E., Hanna, A.A. (eds.) Proceedings of the $2^{\text {nd }}$ international conference on Africanized honey bees and bee mites, A.I. Root Co., Medina, Ohio pp. 150-166. 